\title{
Application of Response Surface Methodology (RSM) for the Production and Optimization of Extruded Instant Porridge from Broken Rice Fractions Blended with Cowpea
}

\author{
Danbaba Nahemiah ${ }^{1,3, ~ *, ~ I r o ~ N k a m a ~}{ }^{2,3}$, Mamudu Halidu Badau ${ }^{3}$ \\ ${ }^{1}$ Food Technology and Value Addition Research Program, National Cereals Research Institute (NCRI), Badeggi, Bida, Niger State, Nigeria \\ ${ }^{2}$ Department of Food Science and Technology, University of Nigeria, Nsukka, Nigeria \\ ${ }^{3}$ Department of Food Science and Technology, University of Maiduguri, Maiduguri, Nigeria
}

Email address:

dnahemiah@gmail.com (D. Nahemiah)

\section{To cite this article:}

Danbaba Nahemiah, Iro Nkama, Mamudu Halidu Badau. Application of Response Surface Methodology (RSM) for the Production and Optimization of Extruded Instant Porridge from Broken Rice Fractions Blended with Cowpea. International Journal of Nutrition and Food Sciences. Vol. 5, No. 2, 2016, pp. 105-116. doi: 10.11648/j.ijnfs.20160502.13

\begin{abstract}
Instant porridge from low grade broken rice fractions blended with cowpea to enhance protein quantity and quality was developed in this study through extrusion cooking technology. Response Surface Methodology (RSM) and Central Composite Rotatable Design (CCRD) were adopted for the formulation and optimization of the process variables. The main objective was to obtain the optimum level of extruder barrel temperature $\left(\mathrm{X}_{1}\right)$, feed moisture level $\left(\mathrm{X}_{2}\right)$ and feed cowpea level $\left(\mathrm{X}_{3}\right)$ that will produce optimum porridge having appreciably high protein, water dispersibility, lysine content and calorie value. ANOVA indicated significance $(p<0.05)$ of the models fitted in describing the relationship between the input and output variables in its natural state. The coefficient of the determination was also greater than $80 \%$ and non-significant lack-of-fit test. Numerical optimization results indicated that the optimum input variables were $120^{\circ} \mathrm{C}$ barrel temperature, $24 \mathrm{~g} / 100 \mathrm{~g}$ cowpea formulation and $20 \mathrm{~g} / 100 \mathrm{~g}$ feed moisture composition which produce $99.02 \%$ dispersibility, $24.13 \mathrm{~g} / 100 \mathrm{~g}$ protein, $73.44 \%$ carbohydrate and $388.82 \mathrm{kcal} / 100 \mathrm{~g}$ calorie, and lysine of $5.02 \mathrm{mg} / \mathrm{g}$ protein. These data will sharpen the weaning food industry by providing wide opportunity for new food production using low grade rice and common legumes, thereby increasing the economic values of both locally grown rice and cowpea.
\end{abstract}

Keywords: Rice, Cowpea, Response Surface Methodology, Optimization, Instant Porridge

\section{Introduction}

In many sub-Saharan African countries including Nigeria, the level of broken grains obtained after rice milling using the village mills (Engelberg) can be as much as $40 \%$ or more (Manful et al., 2004). Such poor-quality rice is often traded at a discount price, reducing the potential margins that could be obtained by rice value-chain actors (Gannon, 1997). The relatively poor quality of locally milled rice in Nigeria and indeed in most of the African countries is one of the primary constraints to further development of the sector (WARDA, 2003). Experts believe that revitalizing the rice sector in terms of both increasing local capacity to compete with imported rice and enhancing value of low quality broken rice through the production of rice-based value added products will improve the market share of locally produced rice greatly (Erenstein and Lancon, 2003).

But, nutritionally, rice and rice-based products are deficient in lysine, an essential amino acid, which can be improved by blending rice with food materials rich in lysine. Food legumes have been proven to be comparatively rich in lysine and therefore combination of rice protein and legume protein provide an ideal source of dietary protein for humans. The utilization of locally grown crops for the production of high protein, shelf stable and affordable recipes in less developed countries has been stressed by international agencies as one of the most suitable channel for addressing the deepening global nutrition challenges (Iwe et al., 2001). Nutritious foods to meet these requirements can be best made from mixture of locally grown cereals and legumes using processing technology that result in shelf stable, convenient and consumer acceptable products using environmentally sustainable 
technology (Iwe, et al. 2001, Nkama and Filli, 2006; Filli and Nkama, 2007) such as extrusion cooking.

Extrusion cooking technology is a continues high temperature short time (HTST) food processing techniques, in which mechanical energy is combined with heat energy to gelatinize starch and denature proteins, plasticizing and reorganizing food materials to create new shaped and textured products, and also has the ability to inactivate enzymes, destroy some toxic substances and reduce microbial activity (Ryu et al., 1993; Abd El-Hady et al., 1998; Ding et al., 2005). It has been used in the cereal industry for several years to produce many foods and food ingredients such as breakfast cereals, snack foods, baby foods, pasta products, extruded bread, modified starches, beverages, powders, meat and cheese analogues, textured vegetable protein, and blended foods such as corn starch and grounded meats (Anderson et al., 1969; Moore et al., 1990; Abd El-Hady et al., 1998; Zang and Hoseney, 1998; Rhee et al., 1999). It is a technology with high versatility and efficiency, low cost, high output per unit time and short reaction time, with relatively no waste generated (Nabeshima and Grossmann, 2001). During extrusion process, chemical modifications and structural changes occurs in the raw materials, such as starch gelatinization (Akdogan, 1999, Van den Einde et al., 2004), protein denaturation (Iwe et al., 2004), pigment and vitamin degradation (Ilo and Berghofer, 1999), and loss of volatile compounds (Bhandani et al., 2001). These changes resulted in new food product with new functional, nutritional and sensory qualities (Bryant, et al., 2001). The knowledge of changes in extruder operating variables therefore provide necessary information for the prediction of what fraction of food materials will undergo specific reaction during extrusion process and its possible effects on the quality of finished product. Ding et al., (2005) reported that little change in extrusion variables such as feed compositions, feed moisture content, screw speed, screw geometry, die configuration; feed rate, processing temperature could greatly affect finished product quality. This therefore has placed a critical need on food scientists to properly and effectively optimize production variables if extrusion technology is to be adopted.

Response surface methodology (RSM) and central composite design (CCD) provides an ideal tool for investigating and optimizing process and product parameters in food processing. RSM is a collection of mathematical and statistical techniques that are useful for modeling and analyzing of problems in which a response of interest is influenced by several variables and the objective is to optimize this response (Montgomery, 1997; Noordin et al., 2004). Several workers (King and Zall, 1992; Filli et al., 2011 and 2012) have used RSM to predict optimum food processing conditions. Optimal process and product design will further improve efficient utilization of broken rice in the production of high quality nutritious products, reduce production cost, and hasten the upscale of these products from pilot status to industrial scale and also facilitate easy troubleshooting and quality control at large scale.
Optimization of extrusion cooking therefore, may involves critical consideration of process parameter, system parameter and product quality.

The current study focuses on the optimization of extrusion parameters in the use of broken rice grain and cowpea for the production of value-added instant porridge using response surface methodology and central composite design.

\section{Materials and Methods}

\subsection{Materials}

Broken rice fractions from the milling of FARO 52 obtained from 2013 rain-fed production were obtained from the National Cereals Research Institute (NCRI) Badeggi, Nigeria, and cowpea (local variety) purchased from the modern market, Bida, Niger State, Nigeria. All samples were manually cleaned and packaged in a sealed polyethylene bags before storage in a cardboard at ambient temperature $\left(32 \pm 2^{\circ} \mathrm{C}\right)$

\subsection{Methods}

Broken rice fractions were blended at different proportion with cowpea flour according to response surface methodology experimental design and extruded at different combinations of extruder barrel temperature and blend moisture composition. The extrudates were pulverized and reconstituted with water. Optimum nutritional composition was determined using standard procedure.

\subsection{Cowpea Flour Preparation}

Cowpea flour was prepared by first steeping $30 \mathrm{~kg}$ in clean tap water for $30 \mathrm{~min}$ at room temperature $\left(32 \pm 2^{\circ} \mathrm{C}\right)$ and dehulled by gently pounding in wooden mortar and pestle followed by several washing and final drying to about 10$12 \%$ moisture levels. Dried cotyledons were then milled in an attrition mill (Locally fabricated) and sieved with fine $(150 \mu \mathrm{m})$ laboratory sieve (Brabender OHG Duisburg). Samples were then packaged in a sealed polyethylene bags at room temperature until required.

\subsection{Rice Flour Preparation}

Broken rice were manually sorted to remove impurities and grounded in an attrition mill (Locally fabricated) and sieved with fine $(150 \mu \mathrm{m})$ laboratory sieve (Brabender OHG Duisburg). Samples were then packaged separately in a sealed polyethylene bags at room temperature until required.

\subsection{Blend Formulation and Moisture Adjustment}

Fifteen (15) formulations were prepared to contain cowpea flour (wet basis) ranging between $8-24 \%$ based on the experimental layout in Table 2. The blended samples were conditioned to appropriate moisture content by spraying with a calculated amount of water and mixing continuously at medium speed in a blender (Laboratory Scale Hobart Mixer, Hobart Corporation, Troy, Ohio, USA). The samples were 
put in closed plastic buckets and stored overnight $\left(32 \pm 2^{\circ} \mathrm{C}\right)$. The feed materials were then allowed to stand for $3 \mathrm{hrs}$ to equilibrate at room temperature prior to extrusion exercise. The amount of water added was calculated using the equation earlier proposed by Ascheri, 2010.

$$
\text { Amount of water to be added }(\mathrm{g})=\frac{\left(M_{f}-M_{i}\right) x S_{w}}{100-M_{f}}
$$

Where $\mathrm{M}_{\mathrm{f}}=$ Final moisture content, $\mathrm{M}_{\mathrm{i}}=$ Initial moisture content and $\mathrm{S}_{\mathrm{w}}=$ Sample weight $(\mathrm{g})$

\subsection{Extrusion Cooking Processing}

The extrusion processing was performed using a corotating twin-screw (SLG 65 Twin-Screw Extruder, Jinan Saibainuo Technology Development Company Ltd, Peoples Republic of China) extruder with an operating screw speed range of 0 to $300 \mathrm{rpm}$, length to diameter ratio of barrel was $20: 1$, while the diameter of the screw was $30 \mathrm{~mm}$. The formulations were introduced manually into the feeding zone through a conical fed hopper at the rate of $30 \mathrm{~kg} / \mathrm{h}$ while avoiding accumulation of fed material, where it first got gelatinized and plasticized under thermal and mechanical energy generated by the double screws; the paste then was cooked and extruded through the die. At a steady state, samples were collected and processed for analysis. The barrel temperature ranges were between $84-140^{\circ} \mathrm{C}$, and feed moisture content was set at $15-24 \%$.

\subsection{Experiment Design and Statistical Analysis}

Table 1. Independent variables and natural levels used for Central Composite Rotatable Design.

\begin{tabular}{|c|c|c|c|c|c|}
\hline \multirow{3}{*}{$\begin{array}{l}\text { Independent } \\
\text { variables }\end{array}$} & \multicolumn{5}{|c|}{ Levels of coded variables } \\
\hline & $-\alpha$ & Low & Medium & High & $+\alpha$ \\
\hline & -1.68 & -1 & $\mathbf{0}$ & 1 & +1.68 \\
\hline $\begin{array}{l}\text { Barrel } \\
\text { Temperature }\left(X_{1}\right)\end{array}$ & 86.36 & 100 & 120 & 140 & 153.64 \\
\hline $\begin{array}{l}\text { Feed Moisture } \\
\text { content }\left(\mathrm{X}_{2}\right)\end{array}$ & 11.59 & 15 & 20 & 25 & 28.41 \\
\hline $\begin{array}{l}\text { Feed } \\
\text { Composition }\left(\mathrm{X}_{3}\right)\end{array}$ & 2.55 & 8 & 16 & 24 & 29.45 \\
\hline
\end{tabular}

Level of each variable was established based on a preliminary extrusion. The distance of the axial points from the centre point was \pm 1.68 , and calculated from Equation $\alpha=\left(2^{\mathrm{n}}\right)^{1 / 4}$ where $\mathrm{n}$ is the number of variables.

The extrusion conditions were optimized with a threefactor five-level central composite rotatable design (CCRD) (Box and Hunter, 1957). Response Surface Methodology (RSM) was used to investigate the effect of the independent variables on the responses. Extruder barrel temperature $\left(\mathrm{X}_{1}\right)$, feed moisture content $\left(\mathrm{X}_{2}\right)$ and formulation cowpea composition $\left(\mathrm{X}_{3}\right)$ were the independent variables considered and the qualities of the finished products were the response variables measured. In order to objectively define the experimental ranges, preliminary experiments were conducted to establish the narrower, more effective ranges of the independent variables $\left(\mathrm{X}_{1}, \mathrm{X}_{2}\right.$, and $\left.\mathrm{X}_{3}\right)$ prior to the experimental runs. As the design value ranges were established, they were coded to lie at $\pm 1 \alpha$ for the factorial points, 0 for the center points and $\pm 1 \alpha$ for axial points. The codes were calculated as a function of the range of interest of each factor as presented in Table 1. The experiments were randomized to maximize the effects of unexplained variability in the observed responses due to extraneous factors, while five replicates at the center of the design were used to allow for estimation of pure error sum of square and lack-of-fit. Analysis of variance (ANOVA) was conducted to determine significant differences among the mean treatment combinations.

Table 2. Outline of experimental design with variables in their coded and un-coded forms.

\begin{tabular}{llll}
\hline \multirow{2}{*}{$\begin{array}{l}\text { Experimental } \\
\text { Runs }\end{array}$} & \multicolumn{3}{l}{ Coded and un-coded Independent variables } \\
\cline { 2 - 4 } & $\mathbf{X}_{\mathbf{1}}\left({ }^{\circ} \mathbf{C}\right)$ & $\begin{array}{l}\mathbf{X}_{\mathbf{2}}\left(\mathbf{g} \mathbf{H}_{\mathbf{2}} \mathbf{O} / \mathbf{g}\right. \\
\text { Sample) }\end{array}$ & $\begin{array}{l}\mathbf{X}_{\mathbf{3}}(\mathbf{g} / \mathbf{1 0 0 g} \\
\text { Sample) }\end{array}$ \\
\hline 1 & $-1(100)$ & $-1(15)$ & $-1(8)$ \\
2 & $1(140)$ & $-1(15)$ & $-1(8)$ \\
3 & $-1(100)$ & $1(25)$ & $-1(8)$ \\
4 & $1(140)$ & $1(25)$ & $-1(8)$ \\
5 & $-1(100)$ & $-1(15)$ & $1(24)$ \\
6 & $1(140)$ & $-1(15)$ & $1(24)$ \\
7 & $-1(100)$ & $1(25)$ & $1(24)$ \\
8 & $1(140)$ & $1(25)$ & $1(24)$ \\
9 & $-1.68(86 . .4)$ & $0(20)$ & $0(16)$ \\
10 & $1.68(153.6)$ & $0(20)$ & $0(16)$ \\
11 & $0(120)$ & $-1.68(11.6)$ & $0(16)$ \\
12 & $0(120)$ & $1.68(28.4)$ & $0(16)$ \\
13 & $0(120)$ & $0(20)$ & $-1.68(2.6)$ \\
14 & $0(120)$ & $0(20)$ & $1.68(29.5)$ \\
15 & $0(120)$ & $0(20)$ & $0(16)$ \\
\hline
\end{tabular}

$\mathrm{X}_{1}=$ Barrel temperature, $\mathrm{X}_{2}=$ Feed moisture content, $\mathrm{X}_{3}=$ Feed cowpea composition. Duplicate runs were carried out at all design point except at the center point where five measurements were carried out and average recorded. The experimental runs were randomized.

\subsection{Process Optimization}

A second order polynomial regression equation was modeled on the basis of the experimental data and optimum parameters defined using Matrix Laboratory (MATLAB 14.13) Software. From the resulting values, for each of the response variable, the coefficients of the polynomial equation $\left(\beta_{o}, \beta_{i}\right.$ and $\left.\beta_{i j}\right)$ are determined and the equation simplified based on the influence of the factors on the final response. The responses were then expressed as second-order polynomial equation according to Eq. 2.

$$
\begin{gathered}
\mathrm{Y}=f(y)=\beta_{0}+\sum_{i=1}^{k} \beta_{i} X_{i}+\sum_{i=1}^{k} \beta_{i i} X_{i}^{2} \\
+\sum_{i=1}^{k} \quad \sum_{i=1}^{k} \beta_{i j} X_{i} X_{j}+\varepsilon
\end{gathered}
$$

Where $\mathrm{Y}$ is the predicted response used as a dependent variable, $k$ is the number of independent variables considered in the experiment; $\beta_{o}$ constant coefficient and $\beta_{i}, \beta_{i j}$ and $\beta_{i i}$ are the coefficient of linear, interaction and square terms respectively, while $\varepsilon$ is the random error term. Multivariate regression analysis with model equation (2) was carried out 
on the data using MINITAB 14.13 statistical software (Manitab Inc. USA) to yield equation 3 which was used to optimize the product responses (Filli et al, 2011).

$$
\begin{aligned}
Y=\beta_{\mathrm{o}} & +\beta_{1} \mathrm{X}_{1}+\beta_{2} \mathrm{X}_{2}+\beta_{3} \mathrm{X}_{3}+\beta_{11} \mathrm{X}_{1}{ }_{1}+\beta_{22} \mathrm{X}_{2}{ }_{2}+\beta_{33} \mathrm{X}_{3}{ }_{3} \\
& +\beta_{12} \mathrm{X}_{1} \mathrm{X}_{2}+\beta_{13} \mathrm{X}_{1} \mathrm{X}_{3}+\beta_{23} \mathrm{X}_{2} \mathrm{X}_{3}+\varepsilon
\end{aligned}
$$

The outline of the experiments with the coded and natural values are presented in Table 2 and to provide homogeneous variance as required for regression models, the data were first transformed to standard scores $\left(z=\frac{\mathrm{x}-\mathrm{X}}{\mathrm{s}}\right)$ where $x$ is the dependent variable of interest, $X$ mean of the dependent variables and $s$ standard deviation.

\subsection{Validation of Fitted Models}

To check if the fitted models provide an adequate approximation to the real system, it is often important to check model adequacy. Unless a model shows adequate fit, proceeding with optimization may lead to misleading results. In this study, numerical validations were conducted on the fitted models. Numerical methods involve the analysis of the coefficient of determination $\left(\mathrm{R}^{2}\right)$ and adjusted coefficient of determination $\left(\mathrm{R}_{\text {adj }}^{2}\right)$ calculated as:

$$
\begin{gathered}
R^{2}=1-\frac{\text { SS residual }}{\text { SS model }+ \text { SS residual }} \\
\text { Adjusted } R^{2}=1-\frac{\mathrm{n}-1}{\mathrm{n}-\mathrm{p}}\left(1-R^{2}\right)
\end{gathered}
$$

Where $S S$ is the sum of squares, $n$ is the number of experiments and $p$ is the number of predictors in the model not counting the constant term. $\mathrm{R}^{2}$ value close to unity and $\mathrm{R}^{2}$ adj close to $\mathrm{R}^{2}$ ensure satisfactory fitting of the model to the real system. Probability value (p-value) was also used to check for the significance of each factor and interaction between the factors. The smaller the $p$-value, the more significant is the corresponding coefficients (Mason et al. 2003). Since triplicate measurements were recorded during analysis of the response variables, a lack-of-fit test was conducted to examine the significance of replicate error in comparison to the model dependent error. This test split the residual or error sum of squares into two parts, one due to pure error as a result of duplicate measurement and the second due to lack-of-fit which is the ratio between the lack-of-fit mean square and pure error mean square. $F$-test can then me used to measure wither the lack-of-fit is statistically significant or not at the described level of probability. Non-significant lack-of-fit was considered desirable.

\subsection{Dispersibility Measurement}

Dispersibility was determined by placing $15 \mathrm{~g}$ of sample in a $100 \mathrm{ml}$ measuring cylinder and adding water to make up to volume, then stir for $1 \mathrm{~min} 30 \mathrm{sec}$ and allowing it to settle for $15 \mathrm{~min}$. The volume of the settled particle was subtracted from 100 and the difference reported as dispersibility in percentage.

\subsection{Proximate Composition}

Protein, fat, ash, dietary fiber, mineral (magnesium, manganese, calcium, zinc, copper and iron) and were determined according to AOAC method (1984). The percentage carbohydrate was calculated by difference. Gross energy value (Kcal/100g) was calculated (FAO, 2002).

\subsection{Amino Acids Profile Analysis}

Amino acids were determined according to methods described by Onyeike et al (2005) as modified by Anyalogbu et al (2015). Five $(5 \mathrm{~g})$ of sample was weighed into extraction thimble of Soxhlet extraction apparatus and $60 \mathrm{ml}$ of chloroform/methanol $(2: 1 \mathrm{v} / \mathrm{v})$ for extraction. This was followed by hydrolysis by weighing the defatted sample into a glass ampoule and $7 \mathrm{ml}$ of $6 \mathrm{MHCl}$ added. The glass ampoule was then sealed with flame from Bunsen burner before incubation at $105 \pm 2{ }^{\circ} \mathrm{C}$ for $22 \mathrm{hr}$ to effect hydrolysis (Nwonsu, et al., 2008). After incubation, the ampoule was allowed to cool to ambient temperature $\left(32 \pm 2^{\circ} \mathrm{C}\right)$ before opening at the tip and the content filtered through filter paper to remove humis. The protein hydrolysate was evaporated to dryness at $40^{\circ} \mathrm{C}$ under vacuum in a rotary evaporator (Buchi Rotavopour Switzerland) and the residual dissolved with $5 \mathrm{ml}$ acetate buffer ( $\mathrm{pH}$ 2.0), in a specimen bottle and stored in a freezer for analysis. $10 \mathrm{ml}$ of the dissolved residual was collected with a micro-syringe and dispensed into the cartridge of the TSM amino acid analyser. The amino acids were separated on the ion-exchange column through a combination of change in $\mathrm{pH}$ and cation strength. The post column reaction between ninhydrin and amino acids eluted from the column formed Riemann's purple, a diketohydrinhylidene-diketohydrindamine (Friedman, 2004). The reaction was therefore monitored at $440 \mathrm{~nm}$ and $570 \mathrm{~nm}$ wavelengths. It took about $1 \mathrm{hr}, 15$ minutes to complete the reaction. Net height of each peak produced by the chart recorder of TSM (each representing an amino) was measured. The half-height of the peak on the chart was found and width of the peak on the half height was accurately measured and recorded. Approximately area of each peak was then obtained by multiplying the height with the width at half-height. Norleucine was added as internal standard and a standard amino acid mixture (Beckman No. 338088, Beckman Coulter, CA) was measured under the same condition as sample. Finally, the amount of each amino acid present in the sample was calculated as $\mathrm{g} / 100 \mathrm{~g}$ protein. The amino acids, leucine, isoleucine, lysine, methionine, phenylalanine, threonine, tryptophan, valine, tyrosine and tryptophan were determined.

\section{Results and Discussion}

\subsection{Model Fitting and Validation}

This study was carried out to produce nutritious extruded instant rice-cowpea porridge and to optimize the production process variables and product quality using response surface 
methodology and central composite design. Process variables considered were barrel temperature $\left(\mathrm{X}_{1}\right)$, feed moisture content $\left(\mathrm{X}_{2}\right)$ and feed cowpea composition $\left(\mathrm{X}_{3}\right)$, while the response variables were dispersibility index, proximate composition and amino acids composition. The mean response values of proximate composition and amino acids profile are presented in Tables 3 and 4 respectively. The independent and response variables were fitted to the second-order model equation (Eq. 2) and its goodness of fit examined using analysis of variance (ANOVA), coefficient of determination $\left(\mathrm{R}^{2}\right.$ and $\mathrm{R}^{2}$ adj), lack-offit test and analysis of residual. The predictive regression models developed for the relationship between the dependent (y) and independent $(\mathrm{X})$ in terms of proximate composition of extruded instant rice-cowpea porridge is presented in Eq. 6 to 12 for moisture, lipid, protein, ash, carbohydrate and caloric value respectively. The coefficients with single factor $\left(\mathrm{X}_{1}, \mathrm{X}_{2}\right.$, and $\mathrm{X}_{3}$ ) represent the independent effect of a particular variable, while coefficients with two of the factors $\left(\mathrm{X}_{1} \mathrm{X}_{2}\right.$, $\mathrm{X}_{1} \mathrm{X}_{3}$, and $\left.\mathrm{X}_{2} \mathrm{X}_{3}\right)$ and the ones with second-order terms $\left(\mathrm{X}_{1}^{2}\right.$, $\mathrm{X}_{2}^{2}$, and $\mathrm{X}_{3}^{2}$ ) represent interaction between the three factors and quadratic effects respectively. A positive sign in front of the regression term is an indication of synergetic relationship, while negative sign indicates an antagonistic relationship.

\section{Moisture}

$5.49148-0.07059 X_{1}-0.05258 X_{2}-0.01937 X_{3}+0.00033 X_{1}^{2}$ $+0.0027 \mathrm{X}_{2}{ }_{2}+0.00093 \mathrm{X}^{2}{ }_{3}-0.00044 X_{1} X_{2}-0.00005 X_{1} X_{3}-$

$$
0.00072 X_{2} X_{3}
$$

\section{Lipid}

$6.85183-0.06165 X_{1}-0.17541 X_{2}-0.14678 X_{3}+0.0002 X^{2}{ }_{1}+$ $0.00272 \mathrm{X}_{2}^{2}+0.00138 \mathrm{X}_{3}^{2}+0.00032 X_{1} X_{2}+0.00043 X_{1} X_{3}+$

$$
0.0017 X_{2} X_{3}
$$

\section{Protein}

$-98.7103+1.5581 X_{1}+3.7519 X_{2}+0.1058 X_{3}-0.0073 X_{1}^{2}-$ $0.0736 \mathrm{X}_{2}^{2}-0.0195 \mathrm{X}_{3}^{2}-0.0018 X_{1} X_{2}+0.0116 X_{1} X_{3}-$ $0.0436 X_{2} X_{3}$

Fibre

$8.90382-0.04286 X_{1}-0.47754 X_{2}+0.04467 X_{3}+0.00026 X^{2}{ }_{1}$ $+0.00999 \mathrm{X}_{2}{ }_{2}+0.00191 \mathrm{X}_{3}{ }_{3}+0.00029 X_{1} X_{2}-0.00143 X_{1} X_{3}$ $+0.00203 X_{2} X_{3}$

Ash

$0.262198+0.00427 X_{1}-0.02886 X_{2}+0.080508 X_{3}-$ $0.000043 X^{2}{ }_{1}-0.000898 X^{2}{ }_{2}-0.000572 X^{2}{ }_{3}+0.000656$

$$
X_{1} X_{2}-0.00034 X_{1} X_{3}-0.000891 X_{2} X_{3}
$$

Carbohydrate

$182.284-1.459 X_{1}-3.051 X_{2}-0.065 X_{3}+0.007 \mathrm{X}_{1}{ }_{1}+0.062 \mathrm{X}_{2}{ }_{2}+$ $0.017 \mathrm{X}_{3}^{2}-0.010 \beta_{13} X_{1} X_{3}+0.040 X_{2} X_{3}$

Calorie value

$397.783-0.160 X_{1}+1.143 X_{2}-1.207 X_{3-} 0.022 \beta_{22} X_{2}^{2}+$ $0.001 \mathrm{X}^{2}{ }_{3}-0.002 X_{1} X_{2}+0.009 X_{1} X_{3}+0.003 X_{2} X_{3}$
While the predictive models representing the relationship between the extruder (process) variables and the response variables in terms of amino acids profile of the instant porridge are outlined in the regression models equation 13 to 20. The results of ANOVA performed on the models to evaluate the significance of the linear, quadratic and interactive effects of the independent variables on the dependent variables are presented in Tables 5 and 6 respectively for proximate and amino acid profiles respectively. This analysis was done using the Fisher's F-test. In this study, the ANOVA indicated significant $(\mathrm{p}<0.05)$ models since probability value is less than 0.05 . The coefficients of determination $\left(\mathrm{R}^{2}\right.$ and $\mathrm{R}^{2}$ adj $)$ results also shows that the proximate composition predictive models $\mathrm{R}^{2}$ values ranged between 59.00 and $99.5 \%$ (Table 5) and $R_{\text {adj varying }}^{2}$ between 40.6 and $99.5 \%$ (Table 6 ). $\mathrm{R}^{2}$ is the ratio of the explained variation to the total variation and measures the degree of fitness of a regression model (Singh et al. 2007; Filli et al. 2011); it therefore defines the proportion of the variability in the observed response variables which is accounted for by regression analysis (McLaren et al., 1977; Filli et al., 2011). The closer the $\mathrm{R}^{2}$ value is to unity, the better the empirical model fits the actual data (Lee and Wang 1997; Zaibunnisa et al., 2009), but the less the value of $\mathrm{R}^{2}$, the less relevant the determinant variables in the model have in explaining variability observed in the response variables. Zaibunnisa et al. (2009) suggested that $\mathrm{R}^{2}$ value should be at least $80 \%$ to have good fit of a regression model. The results of this study therefore showed that the model for all the response variables were highly adequate to explain the variability in response because they have satisfactory level of $\mathrm{R}^{2}$ which is higher than $80 \%$ and $\mathrm{R}_{\text {adj }}^{2}$ that is close to $\mathrm{R}^{2}$. But that of moisture content was less than $80 \%$ and is likely be as non-significance of some terms added in the model.

As repeated measurements were carried out during the data generation, lack-of-fit test which indicate the significance of the replicate error in comparison with the model dependent error was carried out. This test split the error sum of squares into two portions, one which is due to pure error and other due to lack-of-fit. F-test was then used to determine wither the lack-of-fit test was significant or not. The results indicated non-significant $(\mathrm{p}<0.05)$ lack-of-fit in both proximate and amino acid profiles (Tables 5 and 6). Nonsignificant lack-of-fit therefore is desired as a significant test indicates that there may be contributions in the regression response relationship that are accounted for by the fitted models. It is appropriate therefore to conclude that the fitted models adequately approximates the responses and can be used satisfactorily for the prediction of any value of the responses within the defined experimental range.

$$
\begin{aligned}
& \text { Lysine } \\
& \begin{array}{c}
-2.6686+0.0633 \mathrm{X}_{1}+0.3289 \mathrm{X}_{2}+0.0329 \mathrm{X}_{3}-0.00005 \mathrm{X}^{2}{ }_{1}- \\
0.0033 \mathrm{X}^{2}{ }_{2}+0.00014 \mathrm{X}_{3}{ }_{3}-0.0015 \mathrm{X}_{1} \mathrm{X}_{2}-0.0008 \mathrm{X}_{1} \mathrm{X}_{3}+ \\
0.00103 \mathrm{X}_{2} \mathrm{X}_{3}
\end{array}
\end{aligned}
$$

\section{Isoleucine}


$-4.5332+0.0729 X_{1}+0.1826 X_{2}+0.1509 X_{3}-0.0002 X^{2}{ }_{1}-$ $0.0021 \mathrm{X}_{2}^{2}-0.00104 \mathrm{X}_{3}^{2}-0.0007 \mathrm{X}_{1} \mathrm{X}_{2} 0.00093 \mathrm{X}_{1} \mathrm{X}_{3}-$ $0.00066 \mathrm{X}_{2} \mathrm{X}_{3}$

(14)

Lucien

$10.5104-0.1743 \mathrm{X}_{1}+0.2673_{2} \mathrm{X}_{2}+0.2458 \mathrm{X}_{3}+0.0015 \mathrm{X}_{1}{ }_{1}+$ $0.0103 \mathrm{X}_{2}^{2}+0.0029 \mathrm{X}_{3}^{2}-0.0052 \mathrm{X}_{1} \mathrm{X}_{2}-0.0035 \mathrm{X}_{1} \mathrm{X}_{3}+$ $0.0008 \mathrm{X}_{2} \mathrm{X}_{3}$

Valine

$11.9071-0.1714 \mathrm{X}_{1}+0.0460 \mathrm{X}_{2}+0.0643 \mathrm{X}_{3}+0.0008 \mathrm{X}_{1}{ }_{1}+$ $0.0019 X_{2}^{2}-0.0012 X_{3}^{2}-0.001 X_{1} X_{2}-0.0001 X_{1} X_{3}-0.0008$ $\mathrm{X}_{2} \mathrm{X}_{3}$

Methionine + Cysteine

$2.3624-0.0361 \mathrm{X}_{1}+0.0357 \mathrm{X}_{2}+0.0315 \mathrm{X}_{3}+0.0003 \mathrm{X}^{2}{ }_{1}+$ $0.0022 \mathrm{X}_{2}^{2}+0.0009 \mathrm{X}_{3}^{2}-0.0010 \mathrm{X}_{1} \mathrm{X}_{2}-0.0004 \mathrm{X}_{1} \mathrm{X}_{3}+$ $0.0006 \mathrm{X}_{2} \mathrm{X}_{3}$

\section{Threonine}

$-4.4485+0.0758 \mathrm{X}_{1}+0.1337 \mathrm{X}_{2}+0.1371 \mathrm{X}_{3}-0.00015 \mathrm{X}^{2}{ }_{1}-$ $0.00153 \mathrm{X}_{2}{ }_{2}-0.00038 \mathrm{X}_{3}{ }_{3}-0.00079 \mathrm{X}_{1} \mathrm{X}_{2}-0.00137 \mathrm{X}_{1} \mathrm{X}_{3}+$ $0.00153 \mathrm{X}_{2} \mathrm{X}_{3}$

\section{Tyrosine + Phenylalanine}

$7.0172-0.0676 \mathrm{X}_{1}+0.0539 \mathrm{X}_{2}-0.0875 \mathrm{X}_{3}+0.0004 \mathrm{X}_{1}^{2}{ }_{1}-$ $0.0008 \mathrm{X}_{2}^{2}+0.0025 \mathrm{X}^{2}{ }_{3}-0.0004 \mathrm{X}_{1} \mathrm{X}_{2}-0.0007 \mathrm{X}_{1} \mathrm{X}_{3}+$ $0.0040 \mathrm{X}_{2} \mathrm{X}_{3}$

\section{Tryptophan}

$12.4167-0.1881 \mathrm{X}_{1}-0.0162 \mathrm{X}_{2}+0.0003 \mathrm{X}_{3}+0.0009 \mathrm{X}^{2}{ }_{1}+$ $0.0036 \mathrm{X}_{2}^{2}+0.0017 \mathrm{X}_{3}{ }_{3}-0.0012 \mathrm{X}_{1} \mathrm{X}_{2}-0.0008 \mathrm{X}_{1} \mathrm{X}_{3}+$ $0.0018 \mathrm{X}_{2} \mathrm{X}_{3}$

\subsection{Instantization of Rice-Cowpea Porridge}

Instant porridges are precooked flakes which are readily reconstitutable upon the addition of water or milk to yield product having cooked texture. This is one of the functional qualities of food products and has significant impact on consumer acceptability of a product because of its convenience in preparation. In this study, the dispersibility of the porridge in water was evaluated to establish it instant reconstitution upon the addition of water. The ability of food particle to be wet without the formation of lumps, with simultaneous disintegration of agglomerates is an indication of its reconstitution in water to give a fine and consistent paste (Kulkarni et al. 1991; Eke-Ejiofor and Owuno, 2012; Otegbayo et al. 2013). Therefore, high dispersibility is required for a food to be considered instant. In this study, the dispersibility of the product (not presented in the Tables) ranged between 98.2 to $99.2 \%$ indicating high reconstitution. These values are higher than 63.0 to $87.0 \%$ earlier reported by Otegbayo et al. (2013). Pulverized food materials are 'instantized' when the surface of each particle is easily wetted and the material rehydrated and particles sink below the surface of the solvent to disperse rapidly through the solvent. This attributes are termed wettability, sinkability, dispersibility and solubility (Filli et al. 2011). For a product to be considered instant therefore, it most completes these stages within a few second. The porridge in this study may therefore be considered an instant porridge.

\subsection{Effects of Processing Variables on Proximate Composition}

The results of mean observed values for proximate composition (moisture, protein, lipid, fibre, ash, carbohydrate and caloric value) for rice-cowpea porridge is presented in Table 3. The moisture content ranged between 0.08 and $0.92 \%$ with an average of $0.51 \%$. The highest moisture content was recorded in sample corresponding to barrel temperature $100^{\circ} \mathrm{C}$, moisture $20 \%$ and feed composition $16 \%$ and the least value in sample extruded at $120^{\circ} \mathrm{C}$ barrel temperature, $20 \%$ moisture and $16 \%$ cowpea content, the moisture content increase with decreasing moisture content. It is also clear from these results that moisture content of extruded sample depend mainly on the extrusion temperature and not on the amount of moisture of raw material or composition of cowpea. These results suggested that the product had low moisture enough to have an extended shelf life. It has also been observed by several authors that in a dry food systems with moisture content between $6 \%$ and $10 \%$, there is a prolong shelf stability, and above this range, the stability of the system could be impeded by both chemical and microbiological agents (Harper and Jansen, 1985; Afoakwa et al. 2006; Asare et al. 2012). The protein content increased from 19.00 to $29.06 \%$ representing about $65.38 \%$ increase when temperature drops from $140^{\circ} \mathrm{C}$ to $120^{\circ} \mathrm{C}$ and when feed moisture and cowpea content of feed increased from 15 to $20 \%$ and 8 to $16 \%$ suggesting proportional increase in protein when rice is fortified with cowpea. Filli et al (2011) reported an increase from 11.23 to 16.23 protein content when millet was fortified with cowpea through extrusion cooking. Protein content of foods are determined as nitrogen multiply by a factor $(\mathrm{Nx} 6.25)$, and apparent protein content is not affected by extrusion temperature as nitrogen is not affected by heat (Pelembe et al., 2002; Filli et al., 2011). The fat content ranged between 0.04 and $0.61 \%$, with the highest value observed in sample extruded at $100^{\circ} \mathrm{C}$ barrel temperature, $15 \%$ moisture and $8 \%$ cowpea. The increase in fat content may be attributed to the possible raising concentration of some non-fat compounds formed by Millard reaction and/or caramelization which are insoluble in organic solvent (El-Samahy et al., 2007). The significantly low fat content implies that this quality parameter needs to be added from other sources into the diet of the consumers of this product especially if it is going to be used as weaning food. Mitzner and co-workers (1984) reported that for a food to be used as complementary formulations, the minimum fat content requirement should be $6 \%$. Both rice and cowpea are low in fat content, in addition, the extruder processing condition affect the little fat present in the raw materials through several reactions including complex formation with 
amylose and protein, oxidation, lipid binding due to interactions with starch and protein's cis and trans isomerization of unsaturated fatty acids and degradation of fat splitting enzymes. All these reactions resulted in fat loss. The fibre contents varied between 1.62 to $2.88 \%$, with the least value recorded in sample extruded at $120^{\circ} \mathrm{C}$ barrel temperature, $20 \%$ moisture and $29.5 \%$ cowpea and the highest value observed in sample corresponding to $140^{\circ} \mathrm{C}$ barrel temperature, $15 \%$ moisture and $8 \%$ cowpea extrusion conditions. During extrusion cooking process, positive effects of the process parameters on the total and soluble fiber has been observed (Rashid, et al., 2015). Insoluble dietary fiber decreased apparently as the process parameters changes. These changes may probably be due to disruptions of covalent and non-covalent bonds in the carbohydrate and protein moieties leading to smaller and more soluble molecular fragments. The ash content which is the indication of mineral content of the extruded instant porridge varied between 0.80 and $1.10 \%$, with the highest value observed in sample corresponding to $140{ }^{\circ} \mathrm{C}$ barrel temperature, $25 \%$ moisture and $8 \%$ cowpea extrusion conditions and the least value seen in sample extruded at $100^{\circ} \mathrm{C}$ barrel temperature, $25 \%$ moisture and $8 \%$ cowpea. These results is contrary to an earlier observation by El-Samahy et al., (2007), who observed significant increase in ash content when cactus pear concentration was increased in a rice-cactus pear extruded samples. With respect to the carbohydrate and calorie values of the rice-cowpea extrudates, the highest values were $72.21 \%$ and $391.01 \mathrm{kcal} / 100 \mathrm{~g}$ in samples $10\left(153.6^{\circ} \mathrm{C}\right.$ barrel temperature, $20 \%$ moisture and $16 \%$ cowpea) and $1\left(100^{\circ} \mathrm{C}\right.$ barrel temperature, $15 \%$ moisture and $8 \%$ cowpea) respectively, while the least values were observed in samples $15\left(120^{\circ} \mathrm{C}\right.$ barrel temperature, $15 \%$ moisture and $24 \%$ cowpea) and $5\left(100^{\circ} \mathrm{C}\right.$ barrel temperature, $15 \%$ moisture and $24 \%$ cowpea) respectively.

Regression coefficients ( $\beta$ - this is the mean change in the response variables for a unit change in the independent variables while holding the other predictors in the model constant) of the effects of the barrel temperature, feed moisture content and feed blend composition on the proximate composition indicated negative linear and interactive effects of these variables on the moisture content (Table 5) and the ANOVA indicates that both linear and quadratic effects were significant $(\mathrm{p}<0.05)$. This implies that increasing the cowpea content may linearly increase the moisture content of the resulting extruded instant porridge. The protein content coefficient of regression also shows that there were significant $(p<0.05)$ linear, quadratic and interactive effects of the process variables on the protein results (Table 5). The negative linear effect suggests that increasing feed cowpea composition, barrel temperature and feed moisture content resulted in decreased protein content in the porridge, while the significance of the linear, quadratic and interactive terms indicated that these changes may not be attributed to a single factor alone. Though, it has been established that increasing protein based component of feed material directly increase product protein content (Phillips et al. 1984; Singh et al. 1991), but because of the effects of high temperature and low moisture content during extrusion, the protein content were reduced due to denaturation. Though the protein content were significantly affected, at a steady state, the protein content produced in this study is above the minimum protein level of $15.7 \%$ recommended by $\mathrm{FAO} / \mathrm{WHO} / \mathrm{UNN}$ (1985) for supplementation feeding. The fat content were significantly $(p<0.05)$ affected by the linear, quadratic and interactive terms, with the quadratic and linear in an antagonistic manner (Table 5), while the ash content were negatively affected by the process variables. These results is contrary to an earlier findings by Obatolu (2002) and Filli et al., (2011) who observed positive relationship between ash content and feed moisture content. Though the ash content is generally low as observed by this workers in cereal/legume extruded formulations, this may likely be as a result of low ash in dehulled beans and polished rice. The calorie content of the porridge was significantly $(p<0.05)$ affected by the process variables and the regression coefficient results indicated synergetic linear effect of feed moisture content and antagonistic effects of feed cowpea composition and barrel temperature.

\subsection{Effects of Processing Variables on Amino Acid Profile}

The mean amino acid composition as affected by the processing parameters is presented in Table 4. The lysine content of the rice-cowpea based porridge recorded the lowest value of $4.12 \mathrm{~g} / 100 \mathrm{~g}$ protein representing $120^{\circ} \mathrm{C}$ barrel temperature, $20 \%$ feed moisture composition and $2.5 \%$ cowpea in the blend, while the highest value of $6.00 \mathrm{~g} / 100 \mathrm{~g}$ protein was observed in sample representing experimental condition of $120^{\circ} \mathrm{C}$ extrusion temperature, $20 \%$ feed moisture composition and $16 \%$ feed cowpea composition (Table 4), this value are higher than the $340 \mathrm{mg} / \mathrm{gN}$ recommended by WHO as recommended dietary allowance (RDA). For the isoleucine content of the extruded ricecowpea formulations, the highest value of 3.20 was recorded in experimental run 2, representing $140^{\circ} \mathrm{C}, 15 \%$ and $8 \%$ barrel temperature, feed moisture and blend composition experimental conditions respectively and the lowest result of $2.41 \mathrm{~g} / 100 \mathrm{~g}$ protein was observed in run $5\left(100^{\circ} \mathrm{C}\right.$ barrel temperature, $15 \%$ feed moisture and $24 \%$ cowpea composition). The leucine content of rice-cowpea based extrudates ranged from $6.45 \mathrm{~g} / 100 \mathrm{~g}$ protein for design point 5 $\left(100^{\circ} \mathrm{C}\right.$ barrel temperature, $15 \%$ moisture content and $24 \%$ feed composition) to $10.74 \mathrm{~g} / 100 \mathrm{~g}$ protein in design point 4 processed at $140^{\circ} \mathrm{C}$ barrel temperature, $25 \%$ feed moisture content and $8 \%$ blend composition (Table 4 ). It is also clear from the results in Table 4 that the valine content varied between $2.15 \mathrm{~g} / 100 \mathrm{~g}$ protein corresponding to design point 14 and extruded at extruder condition of $120^{\circ} \mathrm{C}$ barrel temperature, $20 \%$ feed moisture content and $16 \%$ cowpea composition, while the highest value of $3.89 \mathrm{~g} / 100 \mathrm{~g}$ protein was recorded in run 4 which correspond to barrel temperature of $140^{\circ} \mathrm{C}$, feed moisture composition of $25 \%$ and $8 \%$ cowpea composition extrusion conditions. 
With regard to methionine + cysteine, the value varied between 1.99 and $2.99 \mathrm{~g} / 100 \mathrm{~g}$ protein, with the lowest value recorded in design 5 and the highest in design 4 which corresponds to extrusion conditions of $100^{\circ} \mathrm{C}$ barrel temperature, $15 \%$ moisture content, $24 \%$ blend composition and $140^{\circ} \mathrm{C}$ barrel temperature, $25 \%$ feed moisture content and $8 \%$ blend cowpea composition respectively (Table 4 ). The threonine composition of rice-cowpea based extruded ranged between 2.32 and $2.95 \mathrm{~g} / 100 \mathrm{~g}$ protein as recorded in designs 14 and 4 respectively. The lowest value was obtained when the extrusion conditions were at $120^{\circ} \mathrm{C}$ barrel temperature setting, $20 \%$ feed moisture and $16 \%$ feed blend composition, while the highest value was recorded at $140^{\circ} \mathrm{C}$ extruder barrel temperature, $25 \%$ feed moisture and
$8 \%$ cowpea composition. While the tyrosine + phenylalanine ranged from $5.28 \mathrm{~g} / 100 \mathrm{~g}$ protein in design 11 corresponding to $120^{\circ} \mathrm{C}$ barrel temperature, $11.6 \%$ feed moisture content and $16 \%$ feed cowpea composition to $8.08 \mathrm{~g} / 100 \mathrm{~g}$ protein in design point 4 representing $140^{\circ} \mathrm{C}$ barrel temperature, $25 \%$ feed moisture composition and $8 \%$ cowpea composition. For the tryptophan content, design point 5 corresponding to $100^{\circ} \mathrm{C}$ barrel temperature, $15 \%$ feed moisture content and $24 \%$ cowpea composition recorded the lowest value of $1.02 \mathrm{~g} / 100 \mathrm{~g}$ protein, while design point 4 corresponding to $140^{\circ} \mathrm{C}$ barrel temperature, $25 \%$ feed moisture and $8 \%$ cowpea composition recorded the highest value of $1.61 \mathrm{~g} / 100 \mathrm{~g}$ protein (Table 4).

Table 3. Mean proximate composition of extruded instant rice-cowpea porridge as affected by extrusion process.

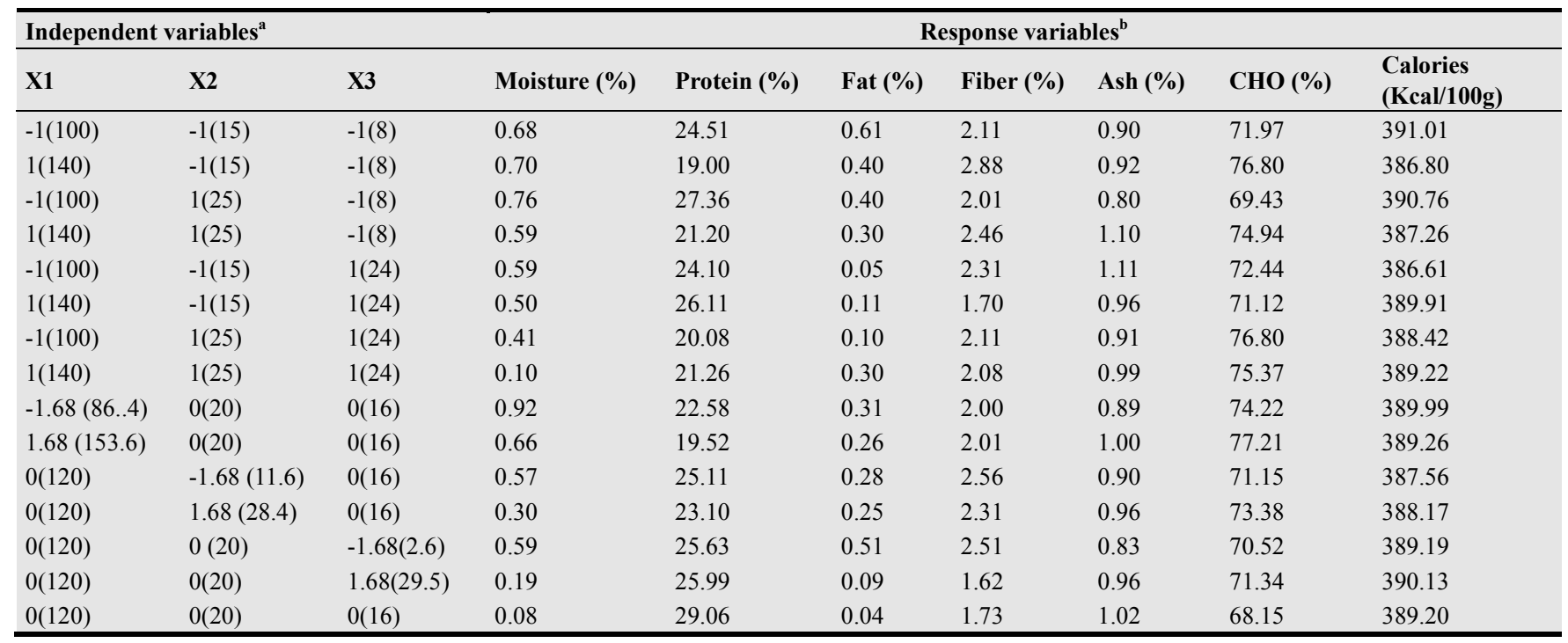

${ }^{\mathrm{a}} \mathrm{X}_{1}=$ barrel temperature $\left({ }^{\mathrm{O}} \mathrm{C}\right), \mathrm{X}_{2}=$ feed moisture content $(\%), \mathrm{X}_{3}=$ feed blend composition $(\%), \mathrm{CHO}=$ carbohydrate. ${ }^{\mathrm{b}}$ Values are mean of triplicate determinations, except at the centre points where five readings were taken and average recorded

Table 4. Mean amino acid composition of extruded instant rice-cowpea porridge as affected by extrusion process.

\begin{tabular}{|c|c|c|c|c|c|c|c|c|c|c|}
\hline \multicolumn{3}{|c|}{ Independent variables $^{\mathrm{a}}$} & \multicolumn{8}{|c|}{ Response variables $^{\mathrm{b}}$} \\
\hline $\mathbf{X}_{1}$ & $\mathbf{X}_{2}$ & $\mathbf{X}_{3}$ & Lysine & ISOLEU & Leusine & Valine & Meth + Cysteine & THRE & TYRO+PHEN & TRYP \\
\hline$-1(100)$ & $-1(15)$ & $-1(8)$ & 4.84 & 2.67 & 7.10 & 3.28 & 2.29 & 2.44 & 6.70 & 1.18 \\
\hline $1(140)$ & $-1(15)$ & $-1(8)$ & 5.44 & 3.20 & 9.98 & 3.77 & 2.74 & 2.90 & 7.80 & 1.50 \\
\hline$-1(100)$ & $1(25)$ & $-1(8)$ & 5.11 & 3.00 & 8.69 & 3.53 & 2.45 & 2.55 & 6.85 & 1.34 \\
\hline $1(140)$ & $1(25)$ & $-1(8)$ & 5.61 & 3.20 & 10.74 & 3.89 & 2.99 & 2.95 & 8.06 & 1.61 \\
\hline$-1(100)$ & $-1(15)$ & $1(24)$ & 4.45 & 2.41 & 6.45 & 2.98 & 1.99 & 2.33 & 5.66 & 1.02 \\
\hline $1(140)$ & $-1(15)$ & $1(24)$ & 5.06 & 2.80 & 7.80 & 3.47 & 2.40 & 2.44 & 6.85 & 1.29 \\
\hline$-1(100)$ & $1(25)$ & $1(24)$ & 5.39 & 3.07 & 9.27 & 3.65 & 2.69 & 2.78 & 7.54 & 1.45 \\
\hline $1(140)$ & $1(25)$ & $1(24)$ & 4.89 & 2.67 & 7.51 & 3.41 & 2.34 & 2.44 & 7.03 & 1.23 \\
\hline$-1.68(86 . .4)$ & $0(20)$ & $0(16)$ & 4.78 & 2.61 & 6.81 & 3.22 & 2.18 & 2.38 & 6.17 & 1.07 \\
\hline $1.68(153.6)$ & $0(20)$ & $0(16)$ & 5.22 & 3.07 & 9.10 & 3.59 & 2.50 & 2.61 & 7.45 & 1.39 \\
\hline $0(120)$ & $-1.68(11.6)$ & $0(16)$ & 4.56 & 2.78 & 7.11 & 3.00 & 2.33 & 2.44 & 5.28 & 1.12 \\
\hline $0(120)$ & $1.68(28.4)$ & $0(16)$ & 5.13 & 2.88 & 6.78 & 2.17 & 2.15 & 2.51 & 5.78 & 1.06 \\
\hline $0(120)$ & $0(20)$ & $-1.68(2.6)$ & 4.12 & 2.79 & 6.77 & 2.18 & 2.15 & 2.52 & 6.02 & 1.05 \\
\hline $0(120)$ & $0(20)$ & $1.68(29.5)$ & 6.00 & 2.77 & 6.79 & 2.15 & 2.14 & 2.32 & 6.10 & 1.06 \\
\hline $0(120)$ & $0(20)$ & $0(16)$ & 5.14 & 2.98 & 6.98 & 3.00 & 2.13 & 2.41 & 5.82 & 1.07 \\
\hline
\end{tabular}

ISOLEU $=$ Isoleucine, Meth $=$ Methionine, THRE $=$ Threonine, TRYO $=$ Tryosine, PHEN $=$ Phenylalanine, TRYP $=$ Tryptophan, $\mathrm{X}_{1}=$ Barrel temperature, $\mathrm{X}_{2}$ $=$ Feed moisture content, $\mathrm{X}_{3}=$ Feed composition. ${ }^{\text {b}}$ Values are mean of triplicate determinations, except at the centre points where five readings were taken and average recorded. The experimental runs were randomized 
Table 5. Estimated regression equation coefficients for response variables (proximate composition) in rice-cowpea instant porridge.

\begin{tabular}{|c|c|c|c|c|c|c|c|}
\hline Term & Moisture & Protein & Fat & Fiber & Ash & СНО & Calories \\
\hline \multicolumn{8}{|l|}{ Linear } \\
\hline $\mathrm{X} 1$ & $-0.07059 * *$ & $-0.06165^{* *}$ & $1.5581 * *$ & -0.04286 & 0.0043 & $-1.459 * *$ & -0.160 \\
\hline $\mathrm{X} 2$ & -0.05258 & $-0.17541^{* *}$ & $3.7519 * *$ & $-0.47754 * *$ & -0.0289 & $-3.051 * *$ & $1.143 * *$ \\
\hline $\mathrm{X} 3$ & -0.01937 & $-0.14678 * *$ & 0.1058 & 0.04467 & $0.0805^{* *}$ & -0.065 & $-1.207 * *$ \\
\hline \multicolumn{8}{|l|}{ Quadratic } \\
\hline $\mathrm{X} 12$ & $0.00033^{* *}$ & $0.00020 * *$ & $-0.0073 * *$ & $0.00026^{* *}$ & -0.00004 & $0.007 * *$ & $<0.0001$ \\
\hline X32 & 0.00093 & $0.00138 * *$ & $-0.0195 * *$ & $0.00191 * *$ & -0.0006 & $0.017 * *$ & 0.001 \\
\hline \multicolumn{8}{|l|}{ Interaction } \\
\hline $\mathrm{X} 12$ & -0.00044 & $0.00032 * *$ & $-0.0018 * *$ & 0.00029 & $0.0007 * *$ & 0.000 & -0.002 \\
\hline $\mathrm{X} 13$ & -0.00005 & $0.00042 * *$ & $0.0116^{* *}$ & $-0.00143 * *$ & $-0.0003 * *$ & $-0.010 * *$ & $0.009 * *$ \\
\hline $\mathrm{X} 23$ & -0.00072 & $0.00170 * *$ & $-0.0436^{* *}$ & 0.00203 & $-0.0009 * *$ & $0.040 * *$ & 0.003 \\
\hline $\mathrm{R} 2$ & 59.0 & 98.2 & 99.5 & 90.8 & 82.3 & 99.5 & 90.6 \\
\hline Lack-of-fit & 0.150 & 1.850 & 233.44 & 79.34 & 0.018 & 0.089 & 0.652 \\
\hline Model & $*$ & $*$ & $*$ & $*$ & $*$ & $*$ & $*$ \\
\hline
\end{tabular}

$Y=\beta_{0}+\beta_{1} X_{1}+\beta_{2} X_{2}+\beta_{3} X_{3}+\beta_{11} X^{2}{ }_{1}+\beta_{22} X^{2}{ }_{2}+\beta_{33} X^{2}{ }_{3}+\beta_{12} X_{1} X_{2}+\beta_{13} X_{1} X_{3}+\beta_{23} X_{2} X_{3}$; $X_{1}=$ Barrel temperature, $X_{2}=$ Feed Moisture content, $X_{3}=$ feed blend composition, $\mathrm{CHO}=$ Carbohydrate, $*$ and $* *=$ significant at $5 \%$ and $1 \%$ level of probability respectively

\subsection{Numerical Process Optimization}

MINITAB's Response Optimizer was adopted for simultaneous numerical optimization of the multiple responses, to search for a combination of independent variables levels that simultaneously satisfy the target requirement placed on each response and factors. Anuar et al., (2013) and Gupta et al (2014) suggested that numerical optimization require that goals (None, Maximum, Minimum, Target or Range) should be set for the independent variables and response where all goals are combined into one desirable function. In this study, sets of conditions that will meet all the goals, the independent variables (i) barrel temperature (100$140^{\circ} \mathrm{C}$ ), (ii) feed moisture content $(15-25 \mathrm{~g} \cdot 100 \mathrm{~g}-1)$ and (iii) feed blend composition (8-24g.100g-1) were all set within range, while protein, water swelling capacity, minerals, fibre, amino acid (lysine) and high acceptability score were set at 5 .
Gupta et al. (2014) reported that the 'importance' score of a goal is within 1 to 5 and setting goal importance at 3 indicates that the variable is considered to be equally important, but Anuar et al. (2013) reported that when it is set at 5 , the response target objective is to meet the objective of getting response at maximum level as applied in this study (Tables 7). The optimum independent variables were found to be $120^{\circ} \mathrm{C}$ barrel temperature, $24 \mathrm{~g} / 100 \mathrm{~g}$ cowpea formulation and $20 \mathrm{~g} / 100 \mathrm{~g}$ feed moisture composition which produce $99.02 \%$ dispersibility, $24.13 \mathrm{~g} / 100 \mathrm{~g}$ protein, $73.44 \%$ carbohydrate and $388.82 \mathrm{kcal} / 100 \mathrm{~g}$ calorie, and lysine of $5.02 \mathrm{mg} / \mathrm{g}$ protein. These results indicated that optimum values can be obtained in the extrusion of rice and soybean that can satisfy both nutritional and functional requirements of instant porridge consumers.

Table 6. Estimated regression equation coefficients for response variables (amino acid profiles) in rice-cowpea extrudates.

\begin{tabular}{|c|c|c|c|c|c|c|c|c|}
\hline Term & Lysine & Isoleucine & Lucien & Valine & Methionine + Cystine & Threonine & Tryptophan + Phen. & Trypt. \\
\hline Constant & $-2.6686^{*}$ & $-4.5332 *$ & $10.5140 *$ & $11.9071 *$ & 2.3624 & -4.4485 & $7.0172 * *$ & $12.4167 * *$ \\
\hline \multicolumn{9}{|l|}{ Linear } \\
\hline $\mathrm{X}_{1}$ & $0.0633^{* *}$ & 0.0729 & $-0.1743 *$ & $-0.1714 * *$ & $-0.0361 *$ & 0.0758 & $-0.0676^{* *}$ & $-0.1781 * *$ \\
\hline $\mathrm{X}_{2}$ & $0.3289 *$ & 0.1826 & 0.2673 & 0.0460 & 0.0357 & 0.1337 & 0.0539 & -0.0162 \\
\hline $\mathrm{X}_{3}$ & 0.0329 & 0.1509 & 0.2458 & $0.0643 *$ & 0.0315 & $0.1371 * *$ & $-0.0875 * *$ & 0.0003 \\
\hline \multicolumn{9}{|l|}{ Quadratic } \\
\hline $\mathrm{X}_{1}^{2}$ & -0.00005 & -0.0002 & $0.0015^{*}$ & $0.0008^{*}$ & $0.0003 *$ & -0.0002 & $0.0004 * *$ & $0.0009 * *$ \\
\hline $\mathrm{X}_{2}^{2}$ & $-0.00325^{*}$ & -0.0021 & $0.0103 *$ & 0.0019 & $0.0022 *$ & -0.0015 & -0.0008 & 0.0036 \\
\hline $\mathrm{X}_{3}^{2}$ & 0.00014 & -0.0010 & $0.0029^{*}$ & -0.0012 & $0.0009^{*}$ & -0.0004 & $0.0025^{* *}$ & $0.0017^{*}$ \\
\hline \multicolumn{9}{|l|}{ Interaction } \\
\hline $\mathrm{X}_{12}$ & $-0.00151^{*}$ & -0.0007 & $-0.0052 *$ & $-0.0010^{*}$ & $-0.0010^{*}$ & -0.0008 & $-0.0004 *$ & $-0.0012^{*}$ \\
\hline $\mathrm{X}_{13}$ & $-0.00084 *$ & -0.0009 & $-0.0035^{*}$ & -0.0001 & $-0.0004 *$ & $-0.0014 *$ & $-0.0007 *$ & $-0.0008^{*}$ \\
\hline $\mathrm{X}_{23}$ & 0.00103* & -0.0007 & 0.0008 & -0.0008 & 0.0006 & 0.0015 & 0.0040 & 0.0018 \\
\hline $\mathrm{R}^{2}$ & 99.90 & 98.90 & 98.90 & 88.90 & 99.50 & 99.50 & 97.30 & 96.80 \\
\hline $\mathrm{R}_{\text {adj }}^{2}$ & 99.70 & 97.00 & 97.00 & 79.00 & 98.50 & 99.80 & 92.40 & 91.00 \\
\hline Lack-of-fit & 0.563 & 0.672 & 0.607 & 0.0740 & 0.0652 & 0.081 & 0.121 & 0.128 \\
\hline Model & $*$ & $*$ & $*$ & $*$ & $*$ & $*$ & $*$ & $*$ \\
\hline
\end{tabular}

$\mathrm{Y}=\beta_{\mathrm{o}}+\beta_{1} \mathrm{X}_{1}+\beta_{2} \mathrm{X}_{2}+\beta_{3} \mathrm{X}_{3}+\beta_{11} \mathrm{X}^{2}{ }_{1}+\beta_{22} \mathrm{X}_{2}{ }_{2}+\beta_{33} \mathrm{X}_{3}{ }_{3}+\beta_{12} \mathrm{X}_{1} \mathrm{X}_{2}+\beta_{13} \mathrm{X}_{1} \mathrm{X}_{3}+\beta_{23} \mathrm{X}_{2} \mathrm{X}_{3} ; \mathrm{X}_{1}=$ Barrel temperature, $\mathrm{X}_{2}=$ Feed Moisture content, $\mathrm{X}_{3}=$ feed blend composition, $*$ and $* *=$ significant at $5 \%$ and $1 \%$ level of probability respectively. 
Table 7. Constraints and goals applied to derive optimum conditions of processing parameters and responses for rice-cowpea based formulations.

\begin{tabular}{|c|c|c|c|c|c|}
\hline Variables & Goal & Lower limit & Upper limit & Importance & Optimum level \\
\hline \multicolumn{6}{|l|}{ Independent variables } \\
\hline Moisture content (\% w.b) & In range & 8 & 24 & 3 & 20 \\
\hline Blend ration (\% legume) & In range & 15 & 25 & 3 & 24 \\
\hline Barrel Temperature $\left({ }^{\circ} \mathrm{C}\right)$ & In range & 100 & 140 & 3 & 120 \\
\hline \multicolumn{6}{|l|}{ Response variables } \\
\hline Dispersibility (DSPLTY) & Maximize & 98.29 & 99.23 & 5 & 99.02 \\
\hline \multicolumn{6}{|l|}{ Proximate composition } \\
\hline Moisture content (\%) & Minimize & 0.08 & 0.92 & 3 & 0.63 \\
\hline Lipid content (\%) & Minimize & 0.04 & 0.61 & 3 & 0.41 \\
\hline Protein $(\%)$ & Maximize & 19.00 & 29.06 & 5 & 24.13 \\
\hline Ash content $(\%)$ & Minimize & 0.80 & 1.11 & 3 & 0.94 \\
\hline Fibre (\%) & Maximize & 1.62 & 2.88 & 5 & 2.00 \\
\hline Carbohydrate (\%) & Minimize & 68.15 & 77.21 & 3 & 73.44 \\
\hline Energy $(\mathrm{kcal} / 100 \mathrm{~g})$ & Maximize & 386.61 & 391.01 & 3 & 388.82 \\
\hline \multicolumn{6}{|c|}{ Amino acid composition (g/100g protein) } \\
\hline Lysine & Maximize & 4.12 & 6.00 & 5 & 5.02 \\
\hline Isoleucine & In range & 2.41 & 3.20 & 3 & 3.00 \\
\hline Leucine & In range & 6.45 & 10.74 & 3 & 8.14 \\
\hline Valine & In range & 2.15 & 3.89 & 3 & 2.68 \\
\hline Methionine + Cysteine & In range & 1.99 & 2.99 & 3 & 2.06 \\
\hline Threonine & In range & 2.32 & 2.95 & 3 & 2.42 \\
\hline Tryptosin + Phenylalanine & In range & 5.28 & 8.06 & 3 & 6.66 \\
\hline Tryptophan & In range & 1.02 & 1.61 & 3 & 1.10 \\
\hline
\end{tabular}

\section{Conclusion}

In this study, different optimum instant porridges were produce from several blends of broken rice fractions and cowpea. The cowpea was added to improve its nutritional quality. Response surface methodology and central composite design were adopted for the formulation and extrusion cooking. Statistically significant regression predictive models were fitted to demonstrate the relationship between the input and output variables. Optimum levels of the input variables that favour optimum production of porridge with high protein, calorie value and appreciable lysine level was achieved. This information can be adopted in the up-scale of extrusion cooking technology where rice and cowpea are the main ingredients. This will also sharpen the weaning food industry by providing wide opportunity for new food production using low grade rice and common legumes, thereby increasing the economic values of both local rice and cowpea.

\section{Acknowledgement}

The authors are grateful for financial support received from Africa Rice Centre (AfricaRice) and the Department of Foreign Affairs, Trade and Development (DFATD) of the government of Canada under the Project number A034968 on "Enhancing food security in Africa through the improvement of rice post- harvest handling, marketing and the development of new rice- based products". Special thank goes to the staff of Food Science and Technology Department, Federal Polytechnic Mubi, Adamawa State for their support during the extrusion exercise.

\section{References}

[1] AOAC. (1984). Official method of Analysis, 14th ed. Association of Official Analytical Chemists Washington D.C.

[2] Abd El-Hady, E. A.; Mostafa, G. A.; El-Samahy, S. K. and ElSaies, I. A. (1998). Production of high fiber corn extrudates. $J$. Agric. Sci. Mansoura Univ., 23(3): 1231-1245.

[3] Anyalogbu E. A., Onyeike. E. N., and M. O Monanu (2015). Effect of heat treatment on the amino acid profile of Plukenetia conophora seed kernel flours. Int. J. Biochem Rese. and Rev. 7(3): 121-131.

[4] Anuar Nordiyanah, Ahmad Faris Mohd Adnan, Naziz Saat, Norkasmani Aziz and Rosna Mat Taha (2013). Optimization of Extraction Parameters by Using Response Surface Methodology, Purification, and Identification of Anthocyanin Pigments in Melastoma malabathricum Fruit. Hindawi Publishing Corporation, The Scientific World Journal Volume 2013, Article ID 810547, 10 pages. http://dx.doi.org/10.1155/2013/810547.

[5] Anderson, R. A., Conway, H. F., Pfeifer, V. F., Griffin, E. L., (1969). Gelatinization of corn grits by roll and extrusion cooking. Cereal Science Today 14(1), 4-12.

[6] Akdogan, H. (1999). Pressure, torque and energy responses of a twin screw extruder at high moisture contents. Food Research International, 29(5-6): 423-429.

[7] Asare EK., Sefa-dedeh S., E. O Afoakwa., E. Sakyi-Dawson and AS Budu (2012). Extrusion cooking of rice-groundnut cowpea mixture-effects of extruder characteristics on nutritive value and physic-functional properties of extrudates using response surface methodology. Journal of food processing and preservation. 36: 465-476 http://dx.doi.org/10111/j.17454549.2011.00605.x. 
[8] Bryant R. J., R. S Kadan., E. J Champagne, B. T Veinyard and B. B Boykin (2001). Functional and digestive characteristics of extruded rice flour. Cereal Chemistry 78: 131-137.

[9] Bhandari, B., B. Darcy and G. Young. 2001. Flavour retention during high temperature short time extrusion cooking process: A review. Intl. J. Food Sci. Technol. 36(1): 453-61.

[10] El-Samahy S.K., Abd El-hady E. A., Habiba R. A and T. E Moussa-Ayoub (2007). Some functional, chemical and sensory characteristics of cactus pear rice-based extrudates. J.PACD-2007: 136-147.

[11] Filli K B, Nkama I (2007). Hydration properties of extruded fura from millet and legumes. Brazilian Food Journal., 109(1): 68-80.

[12] Filli K. B, I. Nkama, V. A. Jideani and U. M. Abubakar (2012). The Effect of Extrusion Conditions on the Physicochemical Properties and Sensory Characteristics of Millet - Cowpea Based Fura. European Journal of Food Research \& Review 2(1): 1-23, SCIENCEDOMAIN international www.sciencedomain.org.

[13] Philips R. D., Chhinnan MS., and Kennedy MB (1984).Effect of feed moisture content and barrel temperature on physical properties of extruded cowpea meal. Journal of Food Science, 49: 916-921.

[14] Singh B, Sekhon KS, Singh N (2007). Effects of moisture, temperature and level of pea grits on extrusion behaviour and product characteristics of rice. Food Chemistry, 110: 198-202.

[15] Ding Q. B., Ainsworth P., Tuker G, and Marson H (2005). The effect of extrusion conditions on the physicochemical properties and sensory characteristics of rice - based expanded snacks. Journal of Food Engineering, 66: 284-289.

[16] Nkama I, Filli KB (2006). Development and Characteristics of Extruded fura from mixtures of pearl millet and grain legumes flours. International Journal of Food Properties, 9: 157-165.

[17] Noordin M. Y., V. C Venkatesh., S. Sharif., S. Elting and A. Abdullah (2004). Application of response surface methodology in describing the performance of coated carbide tools when turning AISI 1045 steel. Journal of Materials Processing Technologies. 145: 46-56. Doi: 10.1016/SO9240136(03)00861-6.

[18] FAO/WHO/UNU (1985). Energy and protein requirements. Tech. Rep. Series 724, Expert Consultation. Geneva: World Health Organization.

[19] Friedman M (2004). Application of the ninhydrin reaction for analysis of amino acids, peptides, and proteins in agricultural and biomedical sciences. Journal of Agriculture and Food Chemistry, 52: 385-406.

[20] Obatolu VA (2002). Nutrient and sensory qualities of extruded malted or unmalted millet/soybean mixture. Food Chemistry, 76: 129-133.

[21] Mitzner, K., Shrimshaw, N., Morgan, R. (1984). Improving the nutritional status of children during weaning period. International Food and Nutrition Program. Cambridge, Massachusetts 02139 USA.

[22] Pelembe, L. A. M., Erasmus, C., Taylor, J. R. N. (2002). Development of a Protein - rich Composite Sorghum Cowpea Instant Porridge by Extrusion Cooking Process. Lebensm-Wiss. U-Technol., 35, 120 - 127.
[23] Harper, J., Jansen, G. (1985). Production of nutritious precooked foods in developing countries by low - cost extrusion technology. Food Review International, 1, 27 - 97.

[24] Mclarem, C. G., Bartolome, V. I., Carrasco, M. C., Quintana, L. C., Ferino, M. I. B., Mojica, J. Z., Olea, A. B., Paunlagui, L. C., Ramos, C. G., Ynalvea, M. A. (1977). Experimental design and data analysis for agricultural research, vol. 1. Los Banos, Laguna: International Rice Research Institute.

[25] Gupta K, Mansi Verma, Payal Jain and Monika Jain (2014). Process Optimization for Producing Cowpea Added Instant Kheer Mix Using Response Surface Methodology. Journal of Nutrition Health Food Engineering, 1(5): 00030.

[26] Rashid S., Rakha A., Anjum F. M., Ahmed W and M. Sohail (2015). Effect of extrusion cooking on the dietary fibre content and water solubility index of wheat bran extrudates International Journal of food Science and Technology, 34:123156. Doi:10.1111/ijfs.12798.

[27] Ryu, G. H.; Neumann, P. E. and Walker, C. E. (1993). Effects of some baking ingredients on physical and structural properties of wheat flour extrudates. Cereal Chemistry, 70(3): 291-297.

[28] Moore, D.; Sanei, E.; Vanhecke, Z. and Bouvier, J. M. (1990). Effect of ingredients on physical/ structural properties of extrudate. Journal of Food Science, 55: 1383-1387, 1402.

[29] Otegbayo, B.O.1, Samuel, F.O.2 and Alalade, T. (2013). Functional properties of soy-enriched tapioca. African Journal $\begin{array}{llll}\text { of } & \text { Biotechnology, } 12 & \text { (22): } & \text { 3583-3589. }\end{array}$ http://dx.doi.org/10.5897/AJB12.2654.

[30] Ilo, S., Liu, Y., and Berghofer, E. (1999). Extrusion cooking of rice flour and amaranth blends. Lebensmittel-Wissenschaft und Technologie, 32, 79-88.

[31] Gannon, R (1997). Rice evolution. Rice Journal, January, 24-26.

[32] WARDA, (2003).Strategy for rice sector revitalization in Nigeria. Project report. WARDA, Abidjan, Cote d'Ivoire, 14p.

[33] Erenstein, O. and F. Lancon, (2003).Report of the Final Technical Workshop, 20-21 August, Ibadan, Nigeria. Project Report. WARDA, Abidjan, Cote d'Ivoire, 24p.

[34] Kulkarni KD, Kulkarni DN, Ingle UM (1991). Sorghum maltbased weaning food formulations: Preparation, functional properties and nutritive value. Food and Nutr. Bull. 13 (4): 322-327.

[35] Iwe, M. O., D. J. Van Zauilichaem, P. O. Ngoody and C. C. Ariahu. (2001). Residence time distribution in a single screw extruder processing soy-sweet potato mixtures. J. Food Sci. Technol. 34(7): 233-239.

[36] Iwe, M. O., van Zuilichem. D. J.. Stolp. W. and Ngoddy, P. O. (2004). Effect of extrusion cocking of soy-sweet potato mixtures on available lysine content and browning index of extrudates. J. Food Engr. 62:143-150.

[37] Manful J.T., Quaye W and Gayin J (2004). Feasibility study on parboiled rice quality improvement program in some selected communities around Tamale in Northern region of Ghana. Report for the Food Security and Rice producers organization project (FSRPOP).CSIR-FRI/RE/MJT/2004/020.

[38] Montgomery D. C (1997). Response surface methods and other approaches to process optimization. In: Design and analysis of experiment. DC Montgomery (Ed.); John Wiley and Sons, New York USA: pp427-510. 
[39] Noordin M. Y., V. C Venkatesh., S. Sharif., S. Elting and A. Abdullah (2004). Application of response surface methodology in describing the performance of coated carbide tools when turning AISI 1045 steel. Journal of materials processing Technologies. 145: 46-56. http://doi: 10.1016/SO924-0136(03)00861-6.

[40] Nwosu J. N, Ubbaonu C. N, Banigo E. O. I, Uzomah A (2008). The effect of processing on amino acid profile of "Oze" (Bosqucia angolensis) seed flour. Life science Journal. 2008; 5(4): 69-74.

[41] Onyeike E. N, Ayalogu E. O, Okaraonye C. C (2005). Nutritive value of the larvae of raphia palm beetles (Oryctes rhinoceros) and weevil (Rhyncophorus pheonicis). Journal of the Science of Food and Agriculture. 2005; 85: 1822-1828.

[42] Filli K. B.., I. Nkama, V. A. Jideani and U. M. Abubakar (2011). Application of response surface methodology for the study of composition of extruded millet-cowpea mixtures for the manufacture of fura: A Nigerian food. African Journal of Food Science 5(17): 884-896. http://www.academicjournals.org/ajfs DOI: 10.5897/AJFS11.169.

[43] Zaibunnisa A. H., S. Norasikin S., S. Mamot and H. Osman (2009). An experimental design approach for the extraction of volatile compounds from turmeric leaves (Curcuma domestica) using Pressurized Liquid Extraction (PLE). Journal of Food Science and Technology 42:233-238.

[44] Eke-Ejiofor J, Owuno F (2012). Functional and Pasting Properties of wheat/three-leaf yam (Dioscorea Dumentorcem) Composite flour blend. Glob. Res. J. Agric. Biol. Sci. 3(4):330-335.

[45] Zhang, W and Hoseney, R. C (1998). Factors affecting expansion of corn meals with poor and good expansion properties. Cereal Chem. 75(5): 639-643.

[46] Rhee, K., Cho, S and Pradahn, A (1999). Composition, storage ability and sensory properties of expanded extrudates from blends of corn starch and goat meat, lamb mutton, spendt fowl meat, or beaf. Meat Sci., 52(2): 135-141.

[47] King V. A. E and R. R Zall (1992). Aresponse surface methodology approach to the optimization of controlled lowtemperature vacuum dehydration. Food Research International 25(1): 1-8.

[48] Nabeshima E. H., and M. V. E Grossmann (2001). Functional properties of pre-gelatinized and cross-linked cassavastarch obtained by extrusion with sodium trimetaphosphate. Carboh. Polym., 45, 347-353. 